\title{
A CRITICAL INVESTIGATION OF THE INTERACTION BETWEEN SECTIONS 8(4)(A), 9H AND PARAGRAPH 40 OF THE EIGHTH SCHEDULE OF THE INCOME TAX ACT No. 58 OF 1962 veRSUS THE CURRENT PRACTICE OF

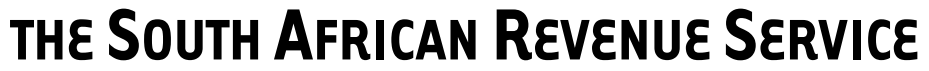

\author{
Carien Straus* \\ Stellenbosch University \\ carienstr@gmail.com
}

Received: March 2014

\author{
Leonard Willemse+ \\ Stellenbosch University \\ Iwillemse@sun.ac.za
}

Accepted: April 2014

\begin{abstract}
Section $9 \mathrm{H}$ and paragraph 40 of the Eighth Schedule of the Income Tax Act No. 58 of 1962 ('the Act') determines that a person is deemed to dispose of all of his assets (bar a few exceptions) at market value when that person ceases to be a South African resident or passes away, respectively. This deemed disposal is treated as a disposal event for capital gains tax purposes in terms of the Eighth Schedule of the Act. The question that arises is whether this deemed disposal event gives rise to a recoupment in terms of section $8(4)(a)$. In practice there currently seems to be uncertainty with regard to this issue, as there are different interpretations and applications of these provisions. This article investigates the interaction between sections $8(4)(\mathrm{a}), 9 \mathrm{H}$ and paragraph 40 of the Eighth Schedule in order to determine whether a section 8(4)(a) recoupment should be included, or not, in the taxpayer's gross income according to paragraph ( $n$ ) of the gross income definition found in section 1 of the Act.
\end{abstract}

Keywords

Income Tax Act No. 58 of 1962 (as amended), recoupment, recouped, recovered, deemed disposal, proceeds

\#Ms C Strauss is lecturer in the Department of Accounting, Stellenbosch University, South Africa.

+Mr LC Willemse is a lecturer in the Department of Accounting, Stellenbosch University, South Africa. 


\section{INTRODUCTION AND BACKGROUND}

Section $9 \mathrm{H}$ and paragraph 40 of the Eighth Schedule ('paragraph 40') of the Income Tax Act No. 58 of 1962 ('the Act') determine that a person is deemed to dispose of all of his assets (bar a few exceptions) at market value as soon as that person, respectively, ceases to be a South African resident or passes away. This deemed disposal is a disposal event for capital gains tax purposes in terms of the Eighth Schedule. The question that arises is whether this deemed disposal event gives rise to a section $8(4)(a)$ recoupment. Currently in practice there is some degree of uncertainty over this issue as there are different interpretations and applications of the aforementioned provisions. This article therefore investigates the interaction between sections $8(4)(\mathrm{a}), 9 \mathrm{H}$ and paragraph 40 of the Eighth Schedule to ultimately determine whether a recoupment should be included (or not) in the taxpayer's gross income as per paragraph ( $n$ ) of the gross income definition in section 1 of the Act.

\section{PROBLEM STATEMENT}

Section 9H came into effect on 8 May 2012 and applies to a person who ceases to be a resident, or becomes a headquarter company (as defined in section 91), or ceases to be a controlled foreign company (as defined in section 9D) in respect of a resident, on or after that date. For the purposes of this article these three events will be referred to as section $9 \mathrm{H}$ events. Section $9 \mathrm{H}$ triggers an exit charge through either a possible capital or income gain for both a company and a person other than a company when the section's requirements are met. It is the result of a deemed disposal by these persons of all of their assets (bar a few exceptions) at market value on the day immediately before the section $9 \mathrm{H}$ events take place (Stiglingh, Koekemoer, van Schalkwyk, Wilcocks \& de Swardt, 2014: 66). The relevant parts of section $9 \mathrm{H}$ read verbatim as follows:

' $9 \mathrm{H}$. Change of residence, ceasing to be controlled foreign company or becoming headquarter company. -

(2) Subject to subsection (4), where a person (other than a company) that is resident ceases during any year of assessment of that person to be a resident -

(a) that person must be treated as having -

(i) disposed of each of that person's assets on the date immediately before the day on which that person so ceases to be a resident for an amount received or accrued equal to the market value of the asset on that date; and ...

(3)(b) Where, during any year of assessment or foreign tax year of a company, the company ceases to be a resident, becomes a headquarter company or ceases to be a controlled foreign company as contemplated in paragraph (a), that company must be treated as having -

(i) disposed of each of that company's assets on the date immediately before the day on which that company so ceased to be a resident, became a headquarter company or ceased to be a controlled foreign company for an amount received or accrued equal to the market value of that asset on that date; and ...'

The nature of the specific type of asset will determine if the gain (if any) which results from the deemed disposal will be capital or income in nature. In the case of an asset which is of a capital nature, the provisions of the Eighth Schedule of the Act will apply. According to Stiglingh et al. 
(2014:883) the tax payable as a result of the deemed disposal in terms of section $9 \mathrm{H}$ is known as an exit charge.

Paragraph 40 regulates the instance where a natural person passes away and determines that the person is deemed to dispose of all of his or her assets (bar a few exceptions) to their deceased estate for an amount equal to the market value of those assets on the date of death (Haupt, 2013:794). The workings of paragraph 40 are similar to that of section $9 \mathrm{H}$ and read verbatim as follows:

'40. Disposal to and from deceased estate - (1) A deceased person must be treated as having disposed of his or her assets, other than -

(a) $\quad \ldots$

for an amount received or accrued equal to the market value of those assets at the date of that person's death.

Section 8(4)(a) applies where a taxpayer recovers or recoups certain amounts that were allowed as deductions or were to be set off in the current or any previous year of assessment (Stiglingh et al., 2014:302). Haupt (2013:212) states that a recoupment will arise where an asset (on which deductions were allowed) is sold for an amount that exceeds its tax value. The difference between the selling price (limited to a maximum amount equal to the original cost of the asset) and the asset's tax value is consequently a taxable recoupment of the deductions previously claimed. This recoupment is included in the taxpayer's gross income in terms of paragraph (n) of the gross income definition found in section 1 of the Act.

From the above it follows that a capital gain or loss has to be calculated in terms of the eighth Schedule where the taxpayer is deemed to dispose of an asset of a capital nature. The capital gain or loss is calculated by subtracting the asset's base cost from the proceeds of the disposal (Stiglingh et al., 2014:875). Paragraph 20 determines which costs form part of the base cost of the asset, whilst paragraphs 35 to 45 regulate the calculation of the proceeds from the disposal. In terms of paragraph 35(1), proceeds equal the amount received by, or accrued to, a person in respect of that disposal (Stiglingh et al., 2014:921). Paragraph 35(3)(a) specifically determines that the amount of proceeds must be reduced by any amount of the proceeds that has to be included in the person's gross income (Haupt, 2013:861). The result of this provision is that when a section $8(4)$ (a) recoupment arises from a disposal, the proceeds of that disposal must be reduced by that recoupment. The purpose is to prevent the taxpayer from being taxed more than once on the same amount, as the recoupment would already have been included in that person's gross income. Furthermore, a recoupment will arise only if it is a tax-deductible asset that is being disposed of or a tax-deductible expense is recovered or recouped. An investigation into the tax treatment of non-tax deductible assets therefore falls outside the scope of this article.

Thus, when a person is deemed to dispose of a depreciable asset for purposes of section $9 \mathrm{H}$ and paragraph 40 , the question arises whether this disposal event gives rise to a recoupment in terms of section 8(4)(a). The South African Revenue Service ('SARS') is of the opinion that a recoupment arises with the application of section $9 \mathrm{H}$, but not with the application of paragraph 40 (Legal \& Policy Division of the South African Revenue Service: Interpretation \& Rulings, 2013). SARS's view causes confusion as both of these provisions determine that a person is deemed to dispose of the relevant assets for an amount received or accrued equal to the market value of those asset(s)'. The provisions make use of exactly the same phrase and words to determine for what amount the asset is disposed of. It is submitted by Badenhorst and Frank (2013), from Exceed Auditing Firm, that SARS's diverse treatment of this issue is confusing and unclear and 
that a consistent and thoughtful treatment is currently lacking. This uncertainty could furthermore lead to tax practitioners (for the sake of prudence) including a section 8(4)(a) recoupment for paragraph 40 purposes in the taxpayer's gross income, possibly to their detriment. The same negative effect could also result if such a recoupment is included in gross income in terms of section 9H (according to SARS's interpretation) if, in actual fact, it does not meet the requirements of section $8(4)(a)$.

Neither section $9 \mathrm{H}$ nor paragraph 40 specifically requires a deemed recoupment to be calculated for purposes of those provisions or for purposes of section $8(4)$ (a). The Act currently does contain provisions which specifically require the calculation of a deemed recoupment such as (amongst others) sections $13 \operatorname{sept}(4), 19,22(8)$ and $23 \mathrm{~F}(3)$. These sections however clearlystate that such a calculation must be made. The fact that clear recoupment guidelines exist for those specific sections in the Act further emphasizes the confusion caused by the diverse interpretation and applications of recoupments in terms of section $9 \mathrm{H}$ and paragraph 40 .

\section{OBJECTIVES AND RESEARCH METHODOLOGY}

The article's main objective is to establish whether a recoupment in terms of section 8(4)(a) arises when the provisions of section $9 \mathrm{H}$ and paragraph 40 apply. To answer this question the meaning of the concepts of "recovered or recouped" as used in section $8(4)(a)$ is investigated. It seems that the current literature has not investigated the interaction between sections $8(4)(\mathrm{a}), 9 \mathrm{H}$ and paragraph 40 in depth, creating a gap that this article aims to bridge. $\mathrm{A}$ qualitative approach based on a literature study of purely theoretical aspects and documentary analysis is used as the research method. The research strategy followed is doctrinal in nature and is described by Hutchinson and Duncan (2012:101) as "research which provides a systematic exposition of the rules governing a particular legal category, analyses the relationships between rules, explains areas of difficulty and, perhaps, predicts future developments". The problembased doctrinal research methodology applied in this article includes the following steps (Hutchinson \& Duncan, 2012:106):

- Assembly of the relevant facts;

- Identification of the applicable legal requirements;

- Analysis of the issue(s) from a legislation point of view;

- Studying of sources such as text books, journal articles etc. as background;

- Use of primary sources such as case law and legislation;

- Synthesising of all issues within the appropriate context; and

- The drawing of an effective and meaningful conclusion.

To reach the abovementioned objectives, the article is structured in the following manner:

- The workings of section $8(4)(a)$;

- Practical illustration of the effect on the taxpayer's taxable income of the different interpretations of section $9 \mathrm{H}$ and paragraph 40 ;

- An investigation of the ordinary dictionary meaning of the words 'recovered' or 'recouped'; 
- An investigation of the meaning of the word 'recouped' as defined by South African case law and academic writers;

- An investigation of the meaning of 'recouped', tax treatment of a change in residence and death, from an international perspective;

- A discussion of the different interpretations of section $9 \mathrm{H}$ and paragraph 40 that currently exists in practice; and

- Summary, conclusion and recommendations.

\section{THE WORKING OF SECTIONS 8(4)(A), 9H AND PARAGRAPH 40 IN SOUTH AFRICA}

In this section the article aims to outline the working of sections $8(4)(\mathrm{a}), 9 \mathrm{H}$ and paragraph 40 by illustrating the interaction between these provisions and investigating the meaning of 'recoupment' as envisaged by section 8(4)(a).

\subsection{The interaction between section $8(4)(a)$ and the deemed disposals in section $9 \mathrm{H}$ and paragraph $\mathbf{4 0}$}

The interaction between section $8(4)(a)$ and the deemed disposals in section $9 \mathrm{H}$ and paragraph 40 will be illustrated by means of an example in the form of TABLE 1 . The example shows the effect of different interpretations regarding a possible recoupment with the deemed disposals in $9 \mathrm{H}$ and paragraph 40 on the tax treatment of these deemed disposals. In Scenario l, the tax treatment is calculated based on the assumption that the deemed disposal in section $9 \mathrm{H}$ and paragraph 40 will trigger a recoupment in terms of section 8(4)(a). Scenario 2 shows the tax treatment should the inverse be true. The different interpretations forming the basis of Scenario 1 and 2 are discussed in section 4.3 .

For purposes of the example below, the following assumptions apply regarding the deemed disposal:

- The taxpayer (natural person) originally acquired the allowance asset at a cost of R100.

- Capital allowances amounting to R60 were claimed on the allowance asset up until the date of the deemed disposal.

- The market value of the allowance asset on the date of the deemed disposal was R120.

- Assume that the taxpayer utilised his annual exclusion in full prior to the deemed disposal. 
TABLE 1: The effect of the different interpretations of section $9 \mathrm{H}$ and paragraph 40 with section $8(4)(a)$

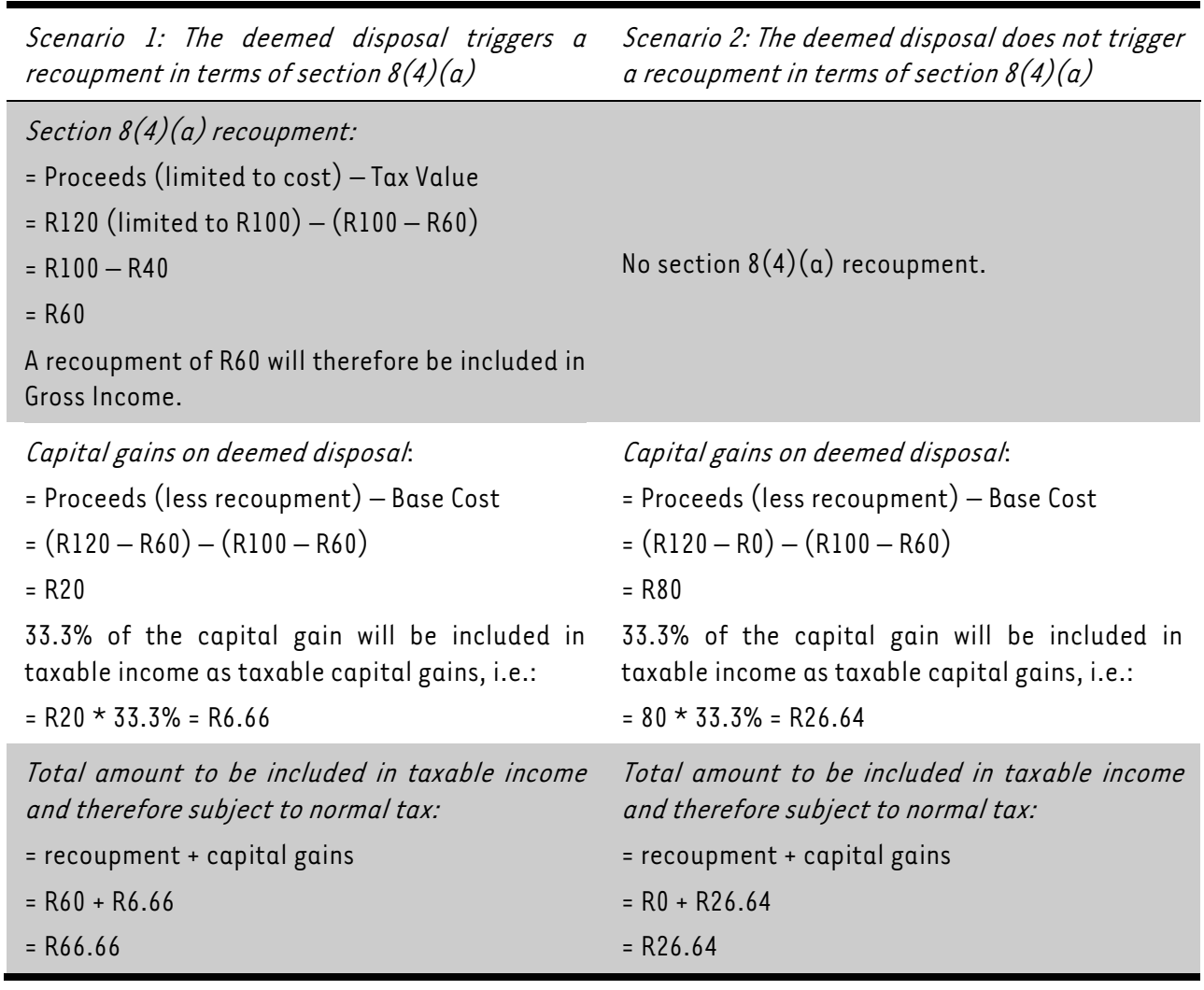

Source: Authors' calculations

The above example shows that the taxable income resulting from the deemed disposal is greater for Scenario 1, which is based on the interpretation that the deemed disposal will trigger a recoupment of allowances previously claimed. This is due to the fact that the recoupment amount, i.e. R60 in the above example, is included in gross income at a rate of $100 \%$. If one is of the view that the deemed disposal will not result in a recoupment, as is the case in Scenario 2, the R60 is treated as a capital gain and therefore included in taxable income at a rate of $33.3 \%$. The result is a difference of approximately R40 $(\mathrm{R} 60 \times(100 \%-33.3 \%))$ in taxable income between the two scenarios. The recoupment in section $8(4)(\mathrm{a})$ therefore directly affects the capital gains resulting from the deemed disposal in that it influences the amount of 'proceeds' used in the calculation of the capital gains.

The above example furthermore illustrates that the gains resulting from the deemed disposal will be subject to tax irrespective of the interpretation (regarding the recoupment) adopted. However, the different interpretations will have an effect on the rate at which the gains will be subject to tax. As shown in the above example, the interpretation followed in Scenario 2 will be more beneficial to the taxpayer as it results in the least amount of taxable income. 


\subsection{The meaning of 'recoupment' as envisaged by section $8(4)(a)$}

\subsubsection{The history and purpose of section $8(4)(a)$}

A general recoupment provision providing for the inclusion in a taxpayer's gross income of previously claimed deductions and allowances that have been recovered or recouped was introduced for the first time in 1941 as section 11(4)(a) of the Income Tax Act 31 of 1941. The main elements of the general recoupment provision have not changed substantially since 1943 (Swart, 2003:464). In C: SARS v Pinestone Properties CC (2001) 63 SATC 421 (at 426) ('Pinestone Properties'), Magid J noted that in ITC 699 (1950) 17 SATC 98 at 104 it was held that s 8(4)(a) of the Act was intended as a method of adjusting over-allowances for depreciation in the past. This view was confirmed by Solomon CJ in CIR v Wolf (1928) 3 SATC 153 (at 156).

Swart (2003:464) states that a general recoupment provision effectively neutralises the deduction, and so denies the taxpayer the benefit of that deduction or allowance. He further states that the function and scope of section $8(4)$ (a) become clear if it is read in conjunction with the prohibition in section 23(c). Swart (2003:464-465) is of the opinion that the above provisions have one feature in common: they allow the deduction of an expense or loss, for tax purposes, only if the person who incurred that expense or loss ultimately bears it (emphasis added).

This begs the question, given the intended purpose of section $8(4)(a)$, whether the passing away of a taxpayer or any of the section $9 \mathrm{H}$ events takes away from the fact that the taxpayer ultimately bore the expense of the allowance asset. This question will be considered below.

\subsubsection{Analysis of the ordinary meaning of the words 'recover' or 'recoup'}

Section 8(4)(a) provides for the inclusion in a taxpayer's gross income of previously claimed deductions and allowances that have been recovered or recouped. The Act, however, does not define the words 'recover' or 'recoup'. According to Clegg and Stretch (2013), words that are not defined in the particular Act itself must be given their ordinary meaning, unless a contrary intention appears (as per Mincer Motors Ltd $v$ Commissioner of Customs and Excise (1958) (1) SA $652(\mathrm{~T})$ ). In Union Government $v$ Mack (1917) AD 731 Solomon J made the following remark at page 739 of the stated case:

\footnotetext{
Now the primary rule in the construction of statutes is that the language of the legislature should be read in its ordinary sense; but this is a rule which is subject to exceptions, and there are many cases in the reports in which the Courts have taken upon themselves to modify the plain meaning of the language ...
}

According to Clegg and Stretch (2013), the courts will deviate from the ordinary meaning of a word in order to give effect to the true intention of the legislature where it appears from the scope and intention of the relevant legislation that the ordinary meaning of a word is in contrast with the intention of the legislature or will lead to an absurdity that was never intended. This view was also supported by the judgement in $R$ Koster \& Son (Pty) Ltd \& another v CIR (1985) 47 SATC 23. In New Union Goldfields Ltd $v$ CIR (1950) (3) SA 392 (A) the court also made it clear that it will not deviate from the ordinary meaning of the word in such a way that it will lead to a complete rewrite of the relevant section of the Act.

Hence, it is submitted that the ordinary meaning of the words 'recover' and 'recoup' can be used, as a starting point, to determine the meaning thereof for purposes of interpreting section 
$8(4)(a)$. This view was also followed in the judgement of Pinestone Properties (at 421), where Magid J stated:

\begin{abstract}
The words 'recovered or recouped' are not terms of art. They must therefore be interpreted according to their ordinary everyday meanings. I have had recourse to the 0xford English Dictionary ('OED') in my investigation of the ordinary meanings of the words.
\end{abstract}

An analysis of the ordinary everyday meaning of 'recover' is 'to get money to make up for (expenses, loss, etc.)' (Chambers Concise Dictionary, 2009:1022) ('Chambers') or to 'get back into one's hands or possession' (Shorter Oxford English Dictionary Volume 2, 2007:2492) ('Oxford'). The ordinary everyday meaning of 'recoup' is 'to recover or get back (something lost, eg money)' (Chambers, 2009:1021) or to 'recover the amount of, make good (a loss, outlay, etc.)' (Oxford, 2007:2492). Magid J investigated the ordinary meaning of the words 'recovered or recouped' in Pinestone Properties and concluded (at 421) as follows:

\footnotetext{
The most appropriate definition of the word 'recover' in the $0 \varepsilon D$ is 'to get ... back again into one's hands or possession; to regain possession of (something lost or taken away).' The OED definition of the word 'recoup' is 'to make up for, compensate for, make good': and that of 'recoupment' is 'the act of recovering or recompensing; the fact of being recouped for loss or expense.'
}

It is submitted, from an analysis of the above, that the cost incurred (and claimed successfully for tax purposes) by a taxpayer can only be viewed as recovered or recouped, in the ordinary meaning of the words, once it has been returned to the pocket of the taxpayer. Support for this view can be found in Omnia Fertilizer Limited v CSARS (2003) 65 SATC 159 ('Omnia Fertilizer'), where Howie P stated (at par. 16):

\begin{abstract}
A more common instance of the ordinary meaning of 'recoup', again according to the Oxford English Dictionary, is 'to recover what one has expended'. To get back what one has actually paid out would be a clear illustration of this meaning." (emphasis added)
\end{abstract}

In Omnia Fertilizer the Supreme Court of Appeal had to consider what constituted a recovery or recoupment for purposes of section $8(4)(a)$. The taxpayer in this case bought material, entered the purchases into its books for the amounts at which it expected to be invoiced and claimed the amounts as income tax deductions in the same year. Certain creditors of the taxpayer failed to invoice it. The taxpayer then credited half the unclaimed amounts to its income account after one year and the balance after two years. The question put before the court was whether the unclaimed amounts had been recovered or recouped in terms of section 8(4)(a) (Strauss, 2003:47). The facts in the 0mnia Fertilizer case however differ from the current investigation in that no cost had actually been incurred by the taxpayer in the Omnia Fertilizer case, whereas costs were incurred by the taxpayer on allowance assets held at the date of deemed disposal in terms of section $9 \mathrm{H}$ and paragraph 40 . The current investigation therefore falls within the ambit of the "more common instance of the ordinary meaning of 'recoup'" as referred to by Howie $P$ above.

It is submitted that the ordinary meaning of the words 'recovered' or 'recouped' is in line with the intention and purpose of section $8(4)(a)$ as discussed in paragraph 4.2.1 above. Section $8(4)$ (a) was written into law as a method of adjusting over-allowances for depreciation in the past. An over-allowance will occur when the amount claimed by the taxpayer for tax purposes exceeds the costs actually incurred by the taxpayer which. This will be the case when costs originally claimed are returned to the pocket of the taxpayer.

It is therefore submitted that the words 'recovered' and 'recouped' should be given their ordinary everyday meaning as laid out above. This approach is sanctioned by Howie $\mathrm{P}$ in Omnia 
Fertilizer (at par. 17-18), where he states that the crucial enquiry, when considering whether a recoupment occurred, is whether costs expended has, for all practical purposes, been returned to the taxpayer's pocket.

\subsection{THE INTERPRETATION FOLLOWED BY THE SOUTH AFRICAN REVENUE SERVICE ('SARS')}

As mentioned earlier in the article, SARS is of the opinion that a recoupment arises with a deemed disposal on emigration (in terms of section $9 \mathrm{H}$ ), but not with a deemed disposal on the passing away of a taxpayer (in terms of paragraph 40 ). This represents an anomaly, as these two provisions (i.e. section $9 \mathrm{H}$ and paragraph 40 ) make use of exactly the same phrase and wording, but trigger different tax treatments according to SARS. It is submitted by the authors that this practice by SARS is not in line with the well-established and trite rule of construction that words should carry the same meaning throughout the Act, unless otherwise indicated.

On page 516 of its Comprehensive Guide to Capital Gains Tax (Issue 4) SARS expresses the opinion that the full market value of a depreciable asset must be brought to account as proceeds for capital gains purposes, as the Act makes no provision for the recoupment of capital allowances on death (Legal and Policy Division of the South African Revenue Service, 2011). This approach by SARS acknowledges and recognises the fact that a mere deemed disposal at market value does not, in itself, trigger a recoupment in terms of section 8(4)(a). In Interpretation Note 12 SARS makes reference to the judgement in ITC 1435 (1987) (50 SATC 117) and refers to the fact that a recoupment can arise only if an allowance asset is sold, destroyed or otherwise disposed of and as a result thereof the taxpayer receives payment in excess of the tax value of the asset. This treatment is also evident in the examples used in Interpretation Note 12.

A different approach, however, is followed by SARS with regard to deemed disposals in terms of section $9 \mathrm{H}$ events. On this occasion, SARS is of the opinion that a recoupment does in fact arise, as the taxpayer is deemed to have received an amount equal to market value as part of the deemed disposal. If it is accepted that the wording used in section $9 \mathrm{H}$ and paragraph 40 should bear the same meaning, it raises the question which one of the two interpretations currently followed by SARS, is in fact, the correct one in law.

The fact that the abovementioned diverse interpretations result in confusion in practice is confirmed by a tax director at Deloitte (Roelofse, 2014). According to the director, the question is not fully settled. He points out that in terms of the Explanatory Memorandum that accompanied the applicable amendment legislation, the view is expressed that there could be a recovery or recoupment. According to him, it is probable that SARS would argue that the capital allowances would be recouped/recovered, on the basis that section $9 \mathrm{H}$ creates a deemed receipt or accrual equal to market value which applies for the purposes of the entire Income Tax Act, including section 8(4)(a) (the recoupment provision). According to Roelofse (2014), the director however goes on to state that:

Against this, one can however argue that although section $9 \mathrm{H}$ does indeed create a deemed receipt/accrual, in order for the taxpayer to recover or recoup a deductible expense, our case law indicates that the taxpayer needs to get back what it has expended/its loss suffered. This is a question of fact and a deemed receipt/accrual in itself cannot create a recovery or recoupment. Thus, given that the taxpayer has not received any actual consideration on ceasing to be South African resident, there can be no recovery or recoupment. It needs to be noted, though, that our case law has never had to consider the recovery/recoupment question 
in the context of a deemed accrual. The question therefore is still an open one with the view

favoured by SARS probably having the inside track.

As pointed out above, the authors are of the opinion that SARS's current treatment of section $9 \mathrm{H}$ events as section 8(4)(a) recoupments has no basis in South African case law to date. The following section provides an insight into the treatment of a change in residence and the passing away of a taxpayer from an international perspective.

\section{THE TAX TREATMENT OF A CHANGE IN RESIDENCE AND DEATH OF A TAXPAYER FROM AN INTERNATIONAL PERSPECTIVE}

For the purposes of this section the tax treatment of a change in residence and death of a taxpayer in Australia and the United Kingdom were investigated. Both of these countries are members of the Organisation for Economic Co-operation and Development ('OECD'), which strives to promote policies that aim to improve the economic and social well-being of people around the world as well as the setting of international standards on a wide range of topics, including $\operatorname{tax}(0 \varepsilon C D,[s . a])$. Although South Africa is not a member of the $0 \varepsilon C D$, it is currently being considered for membership of this prestigious organisation. With this in mind, a view in harmony with the OECD is surely well-advised (Strauss, 2011:3).

It is furthermore submitted that Australian income tax legislation shares a number of similarities with South African income tax legislation (Haupt, 2013:5), as the Act had its origins in the New South Wales Act of 1985. The comparability of the two countries' income tax structures is also mentioned by Judge Wunsh in CIR v Manganese Metal Co (Pty) Ltd (1996) 58 SATC 1.

For the reasons stated above, the authors are of the opinion that an investigation into the two selected countries' tax treatment of the issues identified could provide useful principles and develop an understanding of practices prevailing internationally. A comparative study is therefore deemed insightful and is believed to add value to a certain extent. The workings and existence (if any) of recoupment provisions similar to that of South Africa's section 8(4)(a) are also investigated.

\subsection{The tax treatment of a change in residence and the death of a taxpayer in Australia}

The Australian income tax legislation relevant to this article is the Income Tax Assessment Act 1997 ('ITAA97'). According to Nair (2013), a Senior Manager at PricewaterhouseCoopers (Adelaide, Australia), Australia has a similar provision to that of South Africa's section 8(4)(a) recoupment provision, called the "balancing adjustment" (subdivision 40-D). Under this rule the excess of the sale proceeds minus the written down value (the cost of the asset less the capital allowances allowed on the asset) is included in assessable income. If, however, the written down value of the asset exceeds the proceeds, the difference can be claimed as a deductible amount from assessable income (Nair, 2013).

Under subdivision 20-A of the ITAA97 (subdivisions 20-10 to 20-55), a taxpayer's assessable income includes an assessable recoupment of a loss or outgoing which is deductible in the current or previous income year, or over more than one income year (Woellner, Barkoczy, Murphy, Evans \& Pinto, 2013:126). The assessable recoupment must be received by way of insurance or 
indemnity as recoupment for any deductible loss or outgoing, or as recoupment for a loss or outgoing that is deductible under of the provisions listed in s 20-30. The term 'recoupment' is defined in s 20-25 and consists of a general definition and five special definitions. The general definition includes any kind of recoupment, reimbursement, refund, insurance, indemnity or recovery, however described, and a grant in respect of the loss or outgoing. It is submitted that this general definition infers that something has to be received by the taxpayer for it to be a recoupment. None of the five special recoupment definitions, however, covers the two scenarios investigated (i.e. change in residence and death), and therefore any in-depth discussion thereof falls outside the scope of this article.

According to Nair (2013), Australia does have a 'deemed disposal' tax fiction, but this applies only to assets like shares or financial interests in mutual funds and not to depreciating assets, which are generally 'real estate'. Depreciating assets are assets on which capital allowances are claimed. Regarding balancing adjustments (covered by subdivision 40-B of the ITAA97), it is not necessary that the sale proceeds (technically called 'termination value') are received in cash it could also be a deemed value or market value. Market value is generally used when an asset (other than cash) is received as proceeds. Market or deemed values are also applied only in specific instances. These events are listed under s 40-300 and s 40-305. Neither a change in residence nor the passing away of a taxpayer is however listed as such specific events. It is therefore submitted that a balancing adjustment is not required in respect of a change in residence or the death of a taxpayer in Australia.

S 118-24 of the ITAA97 determines that a capital gain or capital loss made from a CGT event (which is also a balancing adjustment event) that happens to a depreciating asset is disregarded if the asset was an asset held where the decline in value of the asset was worked out under Division 40 of the ITAA97 (the capital allowances division). From this it follows that the disposal of a depreciating asset does not have any CGT consequences but only normal assessable income implications if the event qualifies as a balancing adjustment event. S 118-24 therefore prevents any double taxation.

A special rule exists in Australian tax legislation that any capital gain or loss made on a CGT asset should be disregarded when a person dies, if that asset passes to his/her legal personal representative (a concept similar to an executor of a deceased estate in South Africa) or to a beneficiary (Australian Taxation Office, 2014a). Once a taxpayer ceases to be an Australian resident for tax purposes, he/she is deemed to dispose of all of his/her assets at their market value (Australian Taxation Office, 2014b). As a change in residence is not listed as a balancing adjustment event, the provisions of s 118-24 would not apply to the depreciable assets of the taxpayer, and would result in the calculation of a capital gain or loss.

In summary, the death of a taxpayer has no CGT consequences if the assets in his/her estate are bequeathed to beneficiaries or the legal personal representative (Woellner et al., 2013:398), nor does it have any normal assessable income implications, as the death of the taxpayer is not regarded as a balancing adjustment (i.e. recoupment) event. The change in residence of an Australian taxpayer does not have any balancing adjustment implications, but it does lead to a CGT event where a capital gain or loss has to be calculated. 


\subsection{The tax treatment of a change in residence and the death of a taxpayer in the United Kingdom}

The United Kingdom ('UK') taxes relevant to this article are Income Tax and Capital Gains Tax ('CGT') (Morse \& Williams, 2012:11-12). CGT taxes the gain represented by the difference between the price at which an item was acquired and the price at which it is sold (Morse \& Williams, 2012:12). As a starting point the UK Income Tax treatment of the purchase and disposal of allowance assets can be summarised as follows:

- The capital cost of an asset is not an allowable expense for income tax purposes in terms of section 33 of the Income Tax (Trading and Other Income) Act 2005 ('ITTOIA'). However, Section 28 of the ITTOIA allows for the deduction of capital allowances (calculated in accordance with the Capital Allowances Act 2001 ('CAA')) from taxable profits (which are similar to South Africa's 'taxable income' concept);

- If an asset constitutes either machinery or plant, capital allowances may be available to a taxpayer who has incurred capital expenditure on acquiring that item wholly and exclusively for trade purposes (Morse \& Williams, 2012:133);

- A 'pooling of assets' system is used in the UK whereby most capital expenditure is allocated to a general pool. The unallowed amounts of expenditure for any asset carried forward from the previous tax year are added to the pool. The capital allowances are then calculated at the relevant percentage of the total amount in the pool (Morse \& Williams, 2012:136);

- When capital assets are sold at a profit, then the amount by which the price received for the asset exceeds the value of the allowance for the asset in the pool must be deducted from the pool (Morse \& Williams, 2012:137);

- If the amount received exceeds the amount in the pool, then this must be corrected by what is called a balancing charge (Foster, 2014). This is a direct offset to reflect the fact that the taxpayer has received more for the asset than the unallowed capital expenditure, so is making a profit against the capital allowances received. The idea is that after the balancing charge is made, the taxpayer will have received a capital allowance equal to, but not more than, the actual cost to the taxpayer of the asset (Morse \& Williams, 2012:137).

From the above it is clear that the disposal of an allowance asset does not result in a recoupment in the UK in the same manner as it would in South Africa through section 8(4)(a). According to Foster (2014) (Technical Manager at Ingenious Media UK), the UK does not have an income item referred to as a recoupment. The effect on the taxable profit of the taxpayer is instead achieved through balancing adjustments to the capital expenditure of assets that can be claimed in future. Effectively, the amount of the taxpayer's future allowances is decreased. The disposal of an allowance asset does however have further CGT consequences for the taxpayer. The workings and consequences of this disposal for CGT purposes are summarised as follows:

- The basic event on which capital gains tax depends is the disposal of the asset - the word disposal carries its ordinary meaning and occurs whenever the owner of an asset divests himself of his entitlement to the asset; thus the ordinary meaning includes sale, exchange and gift (Morse \& Williams, 2012:255). 
- CGT is levied on the amount of chargeable gain realised from the disposal - the amount of a chargeable gain or of an allowable loss is arrived at by comparing the consideration received on the disposal of the asset with the cost of its acquisition (Morse \& Williams, 2012:286).

- Consideration is basically the gross money price paid (if the consideration is in money's worth it can be valued) - from this has to be excluded any sum which is charged to or taken into account for income tax (Morse \& Williams, 2012:287). It is submitted that, because the UK has no recoupment provision similar to that of section $8(4)(a)$, no recoupment is included in taxable profit and therefore the consideration received is not decreased by any recoupment amount as would be the case in South Africa.

- The gain (or loss) is computed by deducting the allowable expenditure (determined by section 38 of the Taxation of Chargeable Gains Act 1992 ('TCGA')) from the consideration (Morse \& Williams, 2012:289) - the concept of allowable expenditure is similar to that of base cost for South African CGT purposes.

The amount of expenditure that may be deducted in respect of a 'wasting asset' is restricted. A wasting asset is essentially an allowance asset and is defined by section 44(1) of the TCGA as an asset which has a predictable life not exceeding 50 years (Morse \& Williams, 2012:293). The residual or scrap value of the asset is deducted from the acquisition cost, and the balance is written off on a straight-line basis over the useful life of the asset (Morse \& Williams, 2012:293). The write-offs essentially take the form of the capital allowances under the CAA. TABLE 2 makes use of an example to illustrate what happens when a wasting asset is disposed of. The example is based on the following assumptions:

- Acquisition price of asset $-€ 10000$;

- Useful life of the asset -30 years;

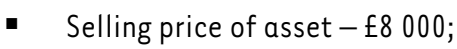

- Residual / scrap value of asset $-£ 1000$; and

- Disposal occurs after 10 years' use.

From the example above it can be inferred that a wasting asset has to be sold for something in order for a chargeable gain to arise. It further follows that no recoupment is calculated, but that the effect of the disposal is taxed through the CGT structure. The full gain realised is therefore subject to CGT.

According to Eden (2014), a Senior Lecturer in Taxation Law at Edinburgh University in Scotland (United Kingdom), and Foster (2014) there is, broadly speaking, no deemed disposal of assets once a person leaves the UK and becomes a non-resident. A charge is however levied on return if that person becomes a UK resident again. The change in residence is therefore not a deemed disposal event as is the case with South African income tax legislation. A non-resident will subsequently be subject to UK tax on income and capital gains derived from the UK only after the change in residence has occurred (HM Revenue \& Customs, [s.a.]). The source of the income and capital gains should therefore be from the UK to be taxable. 
TABLE 2: The UK-CGT effect of a disposal of a wasting asset

\begin{tabular}{lcc}
\hline & Note & Amount \\
\hline Proceeds of sale & & $£ 8000$ \\
Less allowable expenditure & 1. & $£ 7000$ \\
Original cost of asset & & $£ 10000$ \\
Deduct allowances claimed & 2. & $(£ 3000)$ \\
Chargeable gain & & $£ 1000$
\end{tabular}

Note 1:

The allowable expenditure is calculated as the cost less the deductions allowed.

Note 2:

The depreciable amount of the asset is calculated as the cost price less the scrap value of the asset:

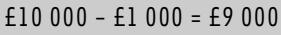

The allowances is then calculated as: $(10 / 30 \times £ 9000)=£ 3000$

Source: Morse and Williams (2012:293-294)

The death of a UK taxpayer has no capital gains tax consequences for him or her (Morse \& Williams, 2012:273), as section 62(1)(b) of the Taxation of Chargeable Gains Act 1992 provides that:

... the assets of which a deceased person was competent to dispose -

(b) shall not be deemed to be disposed of by him on his death ...

The passing away of a taxpayer will therefore have no immediate capital gains tax consequences for the deceased. A tax similar to South Africa's Estate Duty, called 'Inheritance Tax', will however come into operation (Foster, 2014). The inheritance tax is levied in terms of section 4(1) of the Inheritance Tax Act 1984 and according to Morse and Williams (2012:343) the section declares that on the death of any person tax shall be charged as if immediately before his death he had made a transfer of value and the value transferred had been equal to the value of his estate immediately before his death. Morse and Williams (2012:343) state that the effect of this provision is that the deceased is deemed to have made a disposition of all of his assets the moment before death. This, however, is only for Inheritance Tax purposes.

In conclusion, from the above it is submitted that no recoupments similar to South Africa's section $8(4)(a)$ are triggered when a taxpayer ceases to be a resident of the UK or passes away. A change in residence and death are not (deemed) disposal events for UK tax purposes. When allowance assets are actually sold for a consideration, an adjustment is made to the future capital allowances that can be claimed and the difference between the consideration received and the allowable expenditure (which is similar to base cost in South Africa) is taxed as a chargeable gain for CGT purposes. 


\section{SUMMARY, CONCLUSIONS AND RECOMMENDATIONS}

Magid J confirmed in Pinestone Properties (at 426-427) that the onus of proof lies with the Commissioner whether an amount has been recovered or recouped. This view was supported by the decision in CIR v Butcher Bros (Pty) Ltd 1945 AD 301 (at 322). At this stage it is unclear what the effect of section 102 of the Tax Administration Act No. 28 of 2011 has on these views held previously by the South African courts. An in-depth investigation on this matter provides an opportunity for future research.

In terms of the interpretation of legislation it is submitted that if a certain meaning is assigned to a certain set of words, the same meaning should be attributed to those words in other sections of the same Act. Kellaway (1995:74) states that if the legislator uses the same word in the same Act, it should have the same meaning. Kellaway's opinion was based on the statement made by Acting Judge Steyn on page 363 of the Appellate Division court case Minister of the Interior v Machadodorp Investments (Pty) Ltd and Another (1957) 2 All SA 395 (A):

... it may reasonably be supposed that out of a proper concern for the intelligibility of its language, it would intend the word to be understood, where no clear indication to the contrary is given, in the same sense throughout the enactment.

It is however also submitted that where it is clear that the legislator's intention with regard to the meaning of a word is different, or that the word should carry a narrower or wider meaning, then the intention of the legislator as contemplated should be adhered to. Support for this view can be found in SIR v Somers Vine (1968) 29 SATC 179, where the view of the courts is confirmed by Taljaard (2001:62) that the use of the same word(s) by the legislator in the same Act should carry the same meaning. If it seems from the Act that this is not the case, however, the courts should be tasked to interpret the relevant legislation (Willemse, 2010:121) (own translation).

From the above it follows that the words 'for an amount received or accrued equal to the market value of those asset(s)', as used in section $9 \mathrm{H}$ and paragraph 40 , must carry the same meaning and interpretation for both of those provisions. It is therefore respectfully submitted that the treatment of any potential recoupment that may arise from the application of these provisions should be the same, consistent, unambiguous and clear. For reasons stated earlier in the article, the writers are of the opinion that a recoupment can arise only if the taxpayer has disposed of his/her/its assets and received some form of quid pro quo in exchange.

As counter-argument, one could hold the view that the intention of the legislator with the enactment of section $9 \mathrm{H}$ differs from the intention with which it enacted paragraph 40 . In order to determine legislative intent recourse can, inter alia, be had to the purpose of an enactment. The stated purpose can be found in the Explanatory Memorandum issued by National Treasury on the relevant Revenue Laws Amendment Bill proposing the enactment (Strauss, 2011:3). The various Explanatory Memoranda issued in this regard commonly refer to section $9 \mathrm{H}$ as an 'exit charge'. It is clear from this designation that section $9 \mathrm{H}$ is penal in nature. Based on this premise, one could reason that the legislator intended for it to be a "catch-all" provision, i.e. triggering a recoupment as well as capital gains tax. However, if one looks at the specific wording of the various Explanatory Memoranda the intention of the legislature is not quite clear. The Explanatory Memorandum issued in 2011 states that "appreciating assets of a capital nature will trigger capital gains (and possibly recoupment)" (emphasis added) (Explanatory Memorandum 2011: 118-119). The succeeding Explanatory Memorandum issued in 2012 contains an example of the tax treatment of an allowance asset in the event of a section $9 \mathrm{H}$ deemed 
disposal. It appears from the example, however, that the mere deemed disposal of the allowance asset at market value does not lead to a recoupment (Explanatory Memorandum 2012: 111). From the above, it appears that the legislature did not give proper consideration to the recoupment question. The Explanatory Memorandum is either silent or vague on this matter. Hence, in the absence of clear legislative intent indicating otherwise, we submit that the words 'for an amount received or accrued equal to the market value of those asset(s)' must carry the same meaning and interpretation throughout the Act.

SARS's diverse treatments of paragraph 40 and section $9 \mathrm{H}$, which are based on the same underlying principles, are deemed incorrect and possibly unfair towards the taxpayer. To solve this problem, the writers recommend the following:

\section{Recommendations:}

- In the event that the legislature intended for the deemed disposal events in section $9 \mathrm{H}$ to be a 'catch-all' provision, we recommend that this intention be made clear and unambiguous. This can be achieved by including a deemed recoupment provision in section $9 \mathrm{H}$ similar to the deemed recoupment provisions included in sections $13 \operatorname{sept}(4), 19,22(8)$ and $23 \mathrm{~F}(3)$. In the alternative, SARS can issue an interpretation note on section $9 \mathrm{H}$ which outlines its understanding of section $9 \mathrm{H}$ as well as provide an example of its intended tax treatment of the section, i.e. the triggering of both capital gains tax and a recoupment.

- In the event that the legislature did not intend for a section $9 \mathrm{H}$ deemed disposal event to automatically trigger a recoupment, we recommend that the recoupment question be answered based on the ordinary meaning of the words 'recovered' and 'recouped'. In terms of the ordinary meaning as studied above, a section $9 \mathrm{H}$ deemed disposal event does not trigger a recoupment, as no cost was returned to the pocket of the taxpayer.

- Given the fact that South Africa is currently being considered for membership of the OECD, (OECD, 2014) it is in the country's best interest to adopt an interpretation that is in harmony with OECD member countries. As shown above, the tax legislation of Australia and the UK (both member countries of the 0ECD) does not provide for a recoupment on either the passing away of a taxpayer or the emigration of a taxpayer. The writers concede that South Africa's status as a developing country hinders a comparison with the tax legislation of economically stable first world countries. However, it is submitted that should South Africa attempt to pursue membership of this prestigious organisation, tax reforms must be made in order to align our tax system with the likes favoured by the OECD. The writers therefore recommend that section $9 \mathrm{H}$ should be interpreted so as to align with the international position, i.e. that a change in tax residency does not trigger a recoupment.

\section{LIST OF REFERENCES}

Australian Taxation Office. (2014a). Capital Gains Tax-Disregarding capital gain or loss on death. [Online] Available: http://www.ato.gov.au/General/Capital-gains-tax/In-detail/Gifts,inheritances-and-decea sed-estates/Deceased-estate-and-CGT/?page $=2 \#$. (Accessed 18 February 2014).

Australian Taxation Office. (2014b). Capital Gains Tax-Cessation of residency. [Online]. Available: http://www.ato.gov.au/General/Capital-gains-tax/In-detail/Events/Summary-of-CGT-eve nts/?page $=10^{\#}$. (Accessed 18 February 2014). 
Badenhorst, D.F. \& Frank, S. (2013). Personal interview. 12 September 2013.

Capital Allowances Act 2001. [Online] Available:

http://www.legislation.gov.uk/ukpga/2001/2/contents. (Accessed 12 January 2014).

Chambers Concise Dictionary. (2009). London: Chambers Harrap Publishers Ltd.

CIR v Butcher Bros (Pty) Ltd 1945 AD 301.

CIR v Manganese Metal Co (Pty) Ltd (1996) 58 SATC 1.

CIR vWolf (1928) 3 SATC 153.

Clegg, D. \& Stretch, R. (2013). Definitions and meaning of words. Income Tax in South Africa [Online]. Available: http://www.mylexisnexis.co.za.ez.sun.ac.za/nxt/gateway.dll?f=templates\$fn= default.htm\$vid=mylnb:10.1048/enu. (Accessed 3 November 2013).

C: SARS v Pinestone Properties (2001) CC 63 SATC 421.

Eden, S. (2014). United Kingdom Tax Treatment of a change in residence, email to L.C. Willemse [Online], 11 February. Available email: Sandra.Eden@ed.ac.uk.

Foster, C. (2014). United Kingdom Tax Treatment of a change in residence and death of a taxpayer, Email to L.C. Willemse [Online], 26 February. Available email: Charlie.foster@ingeniousmedia. co.uk. Haupt, P. (2013). Notes on South African Income Tax 2013. Roggebaai: H \& H Publications.

HM Revenue \& Customs. (2014). Income Tax when leaving the UK [Online]. Available: http://www.hmrc.gov.uk/incometax/tax-leave-uk.htm. (Accessed 19 February 2014).

Hutchinson, T. \& Duncan, N. (2012). Defining and describing what we do: Doctrinal legal research. Deakin Law Review, 17(1): 83-119.

Income Tax Assessment Act 1997 Act No. 38 of 1997 of Australia as amended.

Income Tax (Trading and Other Income) Act 2005. [Online] Available:

http://www.legislation.gov.uk/ukpga /2005/5/section/34. (Accessed 3 February 2014).

Inheritance Tax Act 1984. [Online] Available:

http://www.legislation.gov.uk/ukpga/1984/51/contents. (Accessed 11 January 2014).

ITC 699 (1950) 17 SATC 98.

ITC 1435 (1987) 50 SATC 117.

Kellaway, દ.A. (1995). Principles of Legal Interpretation of Statutes, Contracts and Wills. Durban: Butterworths.

Legal and Policy Division of the South African Revenue Service: Interpretation \& Rulings. (2013). Workings of section $8(4)$ (a) with section $9 \mathrm{H}$ and paragraph 40, email to L.C. Willemse [0nline], 18 June. Available email: pbothe@sars.gov.za.

Legal and Policy Division of the South African Revenue Service. (2011). Comprehensive Guide to Capita/ Gains Tax $4^{\text {th }} /$ ssue [Online]. Available: http://www.sars.gov.za/AllDocs/OpsDocs/Guides /LAPD-CGT-G01\%20-\%20Comprehensive\%20Guide\%20to\%20Capital\%20Gains\%20Tax\%20\%20External\%20Guide.pdf. (Accessed 16 February 2014).

Minister of the Interior v Machadodorp Investments (Pty) Ltd \& Another (1957) 2 All SA 395 (A).

Morse, G. \& Williams, D.W. (2012). Davies: Principles of Tax Law, th edition. London: Sweet \& Maxwell. 
Nair, V. (2013). Treatment of recoupments in Australian Taxation, Email to L.C. Willemse [Online], 4 September. Available email: vikram.nair@au.pwc.com.

National Treasury Explanatory Memorandum on the Revenue Laws Amendment Bill, 2011. [Online] Available: http://www.sars.gov.za/AllDocs/LegalDoclib/ExplMemo/LAPD-LPrep-EM-2011-02\% 2 0\%20Explanatory\%20Memorandum\%20Taxation\%20Laws\%20Amendment\%20Bill\%202011.pdf. (Accessed 6 March 2014).

National Treasury Explanatory Memorandum on the Revenue Laws Amendment Bill, 2012. [Online] Available: http://www.sars.gov.za/AllDocs/LegalDoclib/ExplMemo/LAPD-LPrep-EM-2012-01\% 2 0\%20Explanatory\%20Memorandum\%20Taxation\%20Laws\%20Amendment\%20Bill\%202012.pdf. (Accessed 6 March 2014).

New Union Goldfields Ltd v CIR (1950) (3) SA 392 (A).

Omnia Fertilizer Limited v CSARS (2003) 65 SATC 159.

Organisation for Economic Co-operation and Development: South Africa and the OECD [Online] Available: http://www.oecd.org/southafrica/southafricaandtheoecd.htm (Accessed 6 March 2014.

Republic of South Africa. (1962). Income Tax Act No. 58 of 1962. Pretoria: Government Printers.

Republic of South Africa. (2011). Tax Administration Act No. 28 of 2011. Pretoria: Government Printers.

R Koster \& Son (Pty) Ltd \& another v CIR (1985) 47 SATC 23.

Roelofse, L. (2014). Tax treatment of section 9H, Email to C. Strauss [Online], 4 February. Available email: cstrauss@sun.ac.za.

Shorter Oxford English Dictionary (Volume 2). (2007). New York: Oxford University Press Inc.

SIR v Somers Vine (1968) 29 SATC 179.

Stiglingh, M., Koekemoer, A., van Schalkwyk, L., Wilcocks, J. \& de Swardt, R. (2014). Silke: South African Income Tax 2014. Pietermaritzburg: LexisNexis.

Strauss, B. (2003). Income Tax. The fertiliser hits the fan! De Rebus, December 2003: 47.

Strauss, C. (2011). An analysis of sections 11D(1)(a) and 11D(5)(b) of the Income Tax Act No. 58 of 1962 as amended. Master's Thesis. Stellenbosch: University of Stellenbosch.

Swart, G. (2003). Recoupments, Accounting Practice, and Income-Tax Principles. SA Mercantile Law Journal, 15(3), pp. 459-478.

Taljaard, J. C. (2001). Geld die gewone reëls en beginsels van wetsuitleg by die uitleg van belastingwetgewing? Master's Thesis. Stellenbosch: University of Stellenbosch.

Taxation of Chargeable Gains Act 1992. [Online] Available:

http://www.legislation.gov.uk/ukpga/1992/12 /enacted. (Accessed l March 2014).

Union Government v Mack (1917) AD 731.

Willemse, L. C. (2010). Die Inkomstebelasting hantering van franchisefooie betaalbaar deur franchisehouers in die Suid-Afrikaanse Petroleumbedryf. Master's Thesis. Stellenbosch: University of Stellenbosch.

Woellner, R.H., Barkoczy, S., Murphy, S., Evans, C. \& Pinto, D. (2013). Australian Taxation Law, $23^{\text {td }}$ edition. Sydney: CCH Publications. 